\title{
Physiological Response and Production Ability of Beef Cattle Raised Based on Different Altitudes in Sinjai Regency
}

\author{
Hermawansyaha, Bahri Syamsuryadi ${ }^{b}$, Iin Mutmainna ${ }^{c}$ \\ $a^{*}, b$ Department of Animal Scince, University of Muhammadiyah Sinjai, Sinjai, South Sulawesi \\ c Department of Agrotechnology, University of Muhammadiyah Sinjai, Sinjai, South Sulawesi
}

email: ${ }^{*}$ hermawansyah.10@gmail.com, ${ }^{b}$ bahrisyamsuryadi25@gmail.com, ${ }^{c}$ iinmutmainna92@gmail.com

\begin{tabular}{|c|c|}
\hline ARTICLE INFO & A B S T R A C T \\
\hline $\begin{array}{l}\text { Article history: } \\
\text { Received } 19 \text { July } 2021 \\
\text { Revised } 26 \text { July } 2021 \\
\text { Accepted } 01 \text { December } 2021 \\
\text { Available online } 31 \\
\text { December } 2021 \\
\end{array}$ & $\begin{array}{l}\text { The breeders' knowledge of the suitability of the breeding environment for } \\
\text { cattle breeds may increase livestock productivity. Determining the differences in } \\
\text { microclimate environmental conditions, physiological responses, and production } \\
\text { capabilities of Bali and Limousine crossbred cattle raised at different altitudes in }\end{array}$ \\
\hline $\begin{array}{l}\text { Keywords: } \\
\text { Beef Cattle } \\
\text { Climate } \\
\text { Physiological } \\
\text { Performance }\end{array}$ & $\begin{array}{l}\text { Sinjai Regency were the aim of this study. The research was carried out on people's } \\
\text { farms in Sinjai, which were divided into three locations based on the height of } \\
\text { different rearing places; low areas }(0-100 \text { masl) were represented by East Sinjai } \\
\text { sub-district, South Sinjai sub-district for medium plains areas (100-400 masl), and } \\
\text { highland areas ( }>400 \text { masl) were represented by West Sinjai sub-district. The } \\
\text { selection was based on the height of the place and beef cattle business in the area. }\end{array}$ \\
\hline $\begin{array}{l}\text { IEEE style in citing this } \\
\text { article: } \\
\text { Hermawansyah, Bahri } \\
\text { Syamsuryadi and Iin } \\
\text { Mutmainna, " Physiological } \\
\text { Response and Production } \\
\text { Ability of Beef Cattle Raised } \\
\text { Based on Different Altitudes } \\
\text { in Sinjai Regency } \\
\text {," Jurnal Ternak, vol. 12, no. } \\
\text { 2, pp. 41- 48, 2021. }\end{array}$ & $\begin{array}{l}\text { The materials used were } 30 \text { Balinese cattle and } 24 \text { Limousine hybrids. This } \\
\text { research was conducted from July to September } 2020 \text {. The method of the research } \\
\text { used direct observation in the field. Data collection used the method of direct } \\
\text { observation in the field. The parameters observed were; microclimate conditions, } \\
\text { physiological responses, and beef cattle production capabilities. The research } \\
\text { found that the altitude of keeping Bali cattle and Limousine breeding affected the } \\
\text { microclimate conditions such as air temperature and humidity in the highlands. } \\
\text { The air temperature is lower in the highlands but the humidity is higher than the } \\
\text { lowlands. Besides, on the physiological response parameters, the altitude effected } \\
\text { on the Limousine hybrid as well as respiratory frequency and pulse rate of Bali } \\
\text { cattle. Respiratory and pulse rates are lower at high altitudes. The height of the } \\
\text { breeding ground also affected the height of the Bali cattle, and the chest } \\
\text { circumference of the Limousine hybrid. }\end{array}$ \\
\hline
\end{tabular}

\section{Introduction}

Indonesia's need for food originating from animal protein of livestock still depends on other countries. The national meat consumption from cattle per capita in 2017 was $0.47 \mathrm{~kg}$ [1]. Fulfilling the people's need for meat currently comes from local cattle such as Bali, Madura and PO cattle as well as imported cattle and imported meat. Imported cows such as Limousine are cows that come from temperate zone. The existence of Limousine cattle from temperate climates in Sinjai regency is thought to be problematic in terms of thermoregulation which will have an impact on livestock productivity.

Beef cattle productivity is influenced by several factors, among others; feed, maintenance management, genetics and microenvironment. The microenvironment that has the most influence is air 
temperature, humidity, wind speed, and the intensity of solar radiation. Extreme environmental conditions due to high temperatures, solar radiation, humidity and low wind speed may cause heat stress on livestock. Heat stress will be a major problem in livestock raising. Regional conditions unfavorable tropics are environmental factors that affect development of livestock at a physiological status that vary. This is a reflection of the condition of livestock on the ability biological activities including production activities and can be seen with changes in the rate of livestock growth [2].

Cattles that are stressed by heat will be reflected in the body's response by increasing the respiratory frequency to remove or replace heat with the surrounding air [3]. The study related to physiological responses and production performance have been carried out by many previous researchers. [4] analyze the physiological responses of Bali cow and heifer that kept under oil palm integrated farming system based on microclimate environment. [5], the respiration profile on a Bali cattle adult female at Bali cattle breeding centers Sobangan village, Mengwi sub district, Badung regency. Performance as raised at different altitude in Bengkulu Transmigration area [6].

The altitude of the place will affect the microclimate environment the cattle are raised. At a suitable height, cattle will be in a comfort zone, thus, they can display optimal production capabilities. On the other hand, at a certain altitude, it is assumed that cows will face environmental stress which will have a negative impact on their productivity. In order to accurately determine the effect of altitude on the physiological response and production capability of beef cattle, it is necessary to conduct a more in-depth study of how the physiological response and production capability of each breed of beef cattle are raised based on different altitudes in Sinjai regency. Knowledge of the environment that is suitable for each cow breed is expected to be able to accelerate population growth in order to increase the income of farmers/breeders. Therefore, the purpose of this study was to determine the differences in microclimate environmental conditions, physiological responses, and production capabilities of Bali cattle and Limousine hybrid raised at different altitudes in Sinjai regency.

\section{Material and Method}

The research was conducted on people's farms in Sinjai regency which were divided into three locations based on the height of different rearing places; low areas (0-100 masl) were represented by East Sinjai sub-district, South Sinjai sub-district for medium plains areas (100-400 masl), and West Sinjai sub-district characterized highland areas (> 400 masl). The area selection was based on the height of the place and the existence of a beef cattle business in the area. The materials used were 30 Bali cattle and 24 Limousine hybrid. This research was conducted from July to September 2020. The main objects used in this study were Bali cattle and Limousine hybrid which were raised in three different locations. The equipment used in this research include; measurement of microenvironment temperature using a digital Thermohygrometer type HTC-2, Temperature Humadity Index (THI) measurement using a wet bulb and dry bulb thermometer, and a stopwatch. Measurement of rectal temperature using a digital clinical thermometer. In measuring the production capability, measuring tape, measuring stick and stationery equipment were used.

\section{Research Procedure}

\section{Measurement of Microclimate Environmental Conditions}

Observation of microclimate environmental conditions was carried out directly (in cages) based on different altitudes. Air temperature and humidity were measured using a thermohygrometer with a duration of 3-5 minutes per observation point. The Temperature Humidity Index (THI) is measured using a wet bulb thermometer and a dry bulb, with a duration of 1 minute for each observation point. The THI calculation was done using the equation [7]:

$$
\mathrm{THI}=\mathrm{Tbk}+(0.36 \cdot(\mathrm{Tbb}))+41.2
$$

Note:

$\mathrm{THI}=$ Temperature humidity index $\left({ }^{\circ} \mathrm{C}\right)$

Tbk $=$ Dry bulb temperature $\left({ }^{\circ} \mathrm{C}\right)$

$\mathrm{Tbb}=$ Wet bulb temperature $\left({ }^{\circ} \mathrm{C}\right)$ 
Measurement of environmental temperature, humidity, and THI was carried out three times a day; in the morning at $7.00 \mathrm{a} . \mathrm{m}$, noon at $12.00 \mathrm{p} . \mathrm{m}$, and in the afternoon at $5.00 \mathrm{p} . \mathrm{m}$. The observations were then averaged.

\section{Physiological Response}

The physiological responses observed in this study were respiratory rate, pulse, and rectal temperature. Respiratory frequency measurements were carried out by observing and counting the frequency of movement of the ribs, abdomen, and/or chest cavity, calculating the frequency of respiration by counting the number of respirations in 1 minute. The measurement of the pulse was done by placing a hand on the coccygeal artery under the middle of the tail about $10 \mathrm{~cm}$ from the anus [7]. Measurements were taken for 1 minute. Rectal temperature was measured using a digital clinical thermometer that was inserted into the rectum $\pm 5 \mathrm{~cm}$ deep for one minute or until the clinical thermometer made a sound.

\section{Production Performance}

Production performance parameters observed were height, body length and chest circumference. Measurements of chest circumference and height were taken when the cattle were standing upright. Chest circumference was measured with a measuring tape on the chest just behind the forelegs [8]. Height measurement was done by measuring the height of the shoulders at the back of the hump (gumba) [9].

\section{Research Design}

ANOVA analysis was used in this research. On production performance parameters used a completely randomized design. Parameters of microclimate conditions and physiological responses used a randomized block design (RBD). The first factor was 3 levels of treatment; the influence of the altitude of the lowlands, medium plains and highlands, while the group factor was 3 levels of observation time, that was morning, afternoon, and evening observations. The difference in the average between the treatments that occurred was then carried out by the Duncan multiple further tests. The mathematical model according to [10] is as follows:

$$
y i j=\mu+\mathrm{p} i+\alpha j+\varepsilon i j
$$

Note:

Yijk = microclimate conditions/physiological response

$\mu \quad=$ general average

$\mathrm{p} i \quad=$ the effect of the $i$ research location

$\alpha j \quad=$ the influence of the $j$ group

Eijk = observation error

\section{Results and Discussion}

\section{Research Location Microclimate Conditions}

The microclimate conditions (in the cage) measured in this study include air temperature, humidity, and Temperature Humidity Index (THI). This parameter was an indicator to determine the microclimate conditions of the rearing place. The average microclimate conditions for Bali cattle and Limousine hybrid maintained based on different altitudes in Sinjai are shown in table 1.

Table 1. Microclimate conditions of research locations based on different altitudes in Sinjai regency.

\begin{tabular}{llll}
\hline \multirow{2}{*}{ Variable } & \multicolumn{3}{c}{ Altitude } \\
\cline { 2 - 4 } & \multicolumn{1}{c}{ Lowland } & Medium land & Highland \\
\hline Air Temperature $\left({ }^{\circ} \mathrm{C}\right)$ & $28.85 \pm 1.47^{\mathrm{b}}$ & $28.87 \pm 2.33^{\mathrm{b}}$ & $21.20 \pm 1.66^{\mathrm{a}}$ \\
Humidity $(\%)$ & $78.21 \pm 6.58^{\mathrm{b}}$ & $75.37 \pm 6.96^{\mathrm{b}}$ & $83.92 \pm 3.73^{\mathrm{a}}$ \\
THI & $73.33 \pm 5.35$ & $73.16 \pm 6.98$ & $76.15 \pm 5.42$ \\
\hline
\end{tabular}

Note: abDifferent superscripts on the same line show significant differences $(\mathrm{P}<0.05)$. 
The statistical analysis illustrated that the air temperature in the highlands was lower and had a statistically significant effect $(\mathrm{P}<0.05)$ compared to the air temperature in the low and medium areas. The low temperature in the highlands was due to different topographic conditions from the low and medium plains. As [11], stated that the highland areas had a more cloudy atmosphere than the medium and lowland areas. This may cause more solar radiation to be absorbed and reflected by the atmosphere which made the intensity of radiation received by the earth is lower. Air temperature is influenced by several factors including the amount of radiation received per year, per day, per season as well as the influence of land or sea, the altitude, indirect wind, latent heat, type and land cover, and the influence of the angle of incidence of sunlight. The air temperature in this study was still in a comfortable range. This is in accordance with the opinion of [12] which stated that the comfortable temperature of cattle kept in tropical areas ranges from $22-30^{\circ} \mathrm{C}$.

Humidity is the amount of moisture in the air. The relative humidity number is from $0-100 \%$, which means $0 \%$ dry air, while $100 \%$ means the air is saturated with water vapor and there will be water droplets. The research found that the humidity in the highlands was statistically different $(\mathrm{P}<0.05)$ from the low and medium plains. This difference is due to the low temperature in the highlands which is 21.20 compared to the low and medium plains (table 1). [13] contended that the lower the air temperature in the cattle pen, the more humidity increases. Other factors that affect humidity are the movement of the wind in the cage, the source of water vapor in the cage, and the air temperature as a controlling factor for the rate of evaporation [14].

The Temperature Humidity Index (THI) is the balance between air temperature and humidity. It is an indicator to determine the comfort level of livestock, the higher the THI value from the optimum range, the higher the heat stress level experienced by livestock. The statistical analysis delineates there is no significant difference at the three research locations. The average value of Temperature Humidity Index (THI) which is the highlands obtained the highest value of 76.15 compared to the lowlands of 73.33, and the moderate plains of 73.16 (table 1). The Temperature Humidity Index (THI) is closely related to the increase in air temperature and humidity, the higher the THI value from the optimum range, the higher the heat stress experienced by livestock. The stress level acceptable to ruminants is calculated using the THI value. [15] conveyed that ruminant are in normal conditions with a THI value $<74$. If indication of the threat of stress reveals in highland locations, it is necessary to have a strategy as a form of anticipation going forward. improvements can be made through improving cage circulation, feed management, nutritional balance and provision of drinking water with ad-lib way.

\section{Physiological Response}

Physiological response is the response of livestock to stress obtained from the surrounding environment. Physiological responses observed in this study included respiratory rate, pulse, and rectal temperature. This variable was one of the indicators to see the response of livestock whether cows were kept at altitudes in Sinjai regency experiencing stress or were in comfortable conditions. The physiological responses of Bali cattle and Limousine hybrid raised based on different altitudes are shown in table 2.

Table 2. Observations of the physiological response of beef cattle breeds reared at different altitudes in Sinjai regency.

\begin{tabular}{|c|c|c|c|c|}
\hline \multirow{2}{*}{ Variable } & \multirow{2}{*}{ Breed } & \multicolumn{3}{|l|}{ Altitude } \\
\hline & & Low & Middle & High \\
\hline Respiratory & \multirow{4}{*}{ Bali Cattle } & & & \\
\hline (times/minute) & & $26.63 \pm 3.45^{\mathrm{a}}$ & $23.67 \pm 1.67^{\mathrm{b}}$ & $21.87 \pm 3.45^{c}$ \\
\hline Pulse (times/minute) & & $44.10 \pm 3.56^{\mathrm{a}}$ & $36.86 \pm 1.67^{b}$ & $40.06 \pm 2.94^{c}$ \\
\hline Rectal Temperature $\left({ }^{\circ} \mathrm{C}\right)$ & & $38.00 \pm 0.95$ & $37.81 \pm 0.89$ & $37.78 \pm 0.95$ \\
\hline Respiratory $\quad$ Frequency & \multirow{4}{*}{$\begin{array}{l}\text { Limousine } \\
\text { Hybrid }\end{array}$} & & & \\
\hline (times/minute) & & $27.63 \pm 2.99 c$ & $24.80 \pm 2.27^{b}$ & $20.17 \pm 1.93^{a}$ \\
\hline Pulse (times/minute) & & $50.23 \pm 4.21^{\mathrm{c}}$ & $42.80 \pm 4.48^{\mathrm{a}}$ & $44.97 \pm 2.86^{\mathrm{b}}$ \\
\hline Rectal Temperature $\left({ }^{\circ} \mathrm{C}\right)$ & & $38.08 \pm 0.30^{\mathrm{b}}$ & $38.38 \pm 0.30^{\mathrm{a}}$ & $38.01 \pm 0.28^{\mathrm{b}}$ \\
\hline
\end{tabular}


Note: abcDifferent superscripts on the same line indicate significant differences $(\mathrm{P}<0.05)$

Respiratory rate and heart rate were higher in the lowlands in both types of cattle. Meanwhile, the rectal temperature of Bali cattle did not differ based on altitude and Limousine crossbreed cattle had the highest rectal temperature in the temperate plains.

Respiration is a physiological process carried out by livestock to take oxygen and release carbon dioxide [4]. The statistical analysis demonstrates that both Bali cows and Limousine ones reared in the highlands obtained lower and statistically different values of respiration frequency $(\mathrm{P}<0.05)$ compared to the respiratory frequency of cows reared in low and medium lands. This indicates that the rearing environment responds differently to both Bali cattle and Limousine hybrid. The results are different from the research by [16] which obtained results of the respiratory frequency of coastal cattle in the lowlands of 18 and 19 in the highlands (times/minute) in West Sumatra. Respiratory frequency of both Bali cows and Limousines in this study were still in the normal range. This is according to Jackson's opinion in [5] which stated that the normal frequency in adult cows is 15-35 times/minute.

The pulse frequency is an illustration of the heart's performance. The increase and decrease in pulse frequency is closely related to the heat load produced both in metabolic processes in the body and the heat load received from the external environment [17] . [18] stated that pulse frequency is influenced by several factors including age, body size, environmental conditions, measurement time, and livestock activity. The statistical analysis explains that the pulse rates of Bali cattle and Limousine hybrid reared based on different altitudes are statistically different $(\mathrm{P}<0.05)$. The pulse rate obtained the highest value in the lowlands compared to the medium plains and highlands. The pulse rate in this study was still in the normal range. Normal pulse rate in beef cattle ranges from 36-80 beats/minute [19].

Rectal temperature is a reflection of the balance of heat produced with the heat released. The statistical analysis delineates that the rectal temperature of Bali cattle reared at different altitudes shows no significant difference. However, the rectal temperature of Limousine hybrid denotes a significant difference $(\mathrm{P}<0.05)$. This difference is due to the air temperature in the mediumlands which is higher $\left(28.87^{\circ} \mathrm{C}\right)$ compared to the air temperature in the low and highlands (Table 1$)$. This condition shows that the altitude for keeping Limousine hybrid cattle in Sinjai regency has an effect on rectal temperature. The rectal temperature of Bali cattle and Limousine hybrid in this study were still in the normal range. This is in accordance with the opinion of [20] which stated that the normal rectal temperature of cattle in the tropics in the range of $38-39.2^{\circ} \mathrm{C}$.

\section{Production Performance}

Body measurements of cattle are comprehensive estimates of body shape and a characteristic description of various body images. Economic-value body dimensions, including body length, gumba height and chest circumference, can be used to describe livestock productivity [6]. The body size in this study includes height, chest circumference, and body length. The average dimensions of the body size of various breeds of beef cattle are kept based on the different heights of the rearing places are shown in (Table 3).

Table 3. Observations of the production performance of various breeds of beef cattle kept at different altitudes in Sinjai district.

\begin{tabular}{|c|c|c|c|c|}
\hline \multirow{2}{*}{ Variable (cm) } & \multirow{2}{*}{ Breed } & \multicolumn{3}{|l|}{ Altitude } \\
\hline & & Lowland & Middle plain & Highland \\
\hline Height & \multirow{3}{*}{ Bali Cattle } & $106.25 \pm 3.14 b$ & $111.94 \pm 1.67 \mathrm{a}$ & $108.16 \pm 2.96 b$ \\
\hline Body Length & & $113.10 \pm 5.57$ & $116.95 \pm 6.64$ & $115.52 \pm 1.00$ \\
\hline Chest Circumference & & $146.89 \pm 4.77$ & $151.26 \pm 4.34$ & $156.10 \pm 14.63$ \\
\hline Height & \multirow{3}{*}{$\begin{array}{l}\text { Limousine } \\
\text { Hybrid }\end{array}$} & $123.00 \pm 9.26$ & $118.70 \pm 10.55$ & $125.98 \pm 3.20$ \\
\hline Body Length & & $129.38 \pm 13.92$ & $125.04 \pm 17.96$ & $133.00 \pm 7.71$ \\
\hline Chest Circumference & & $137.24 \pm 9.89 b$ & $144.10 \pm 19.67 \mathrm{~b}$ & $173.02 \pm 5.52 \mathrm{a}$ \\
\hline
\end{tabular}

Note: abcDifferent superscripts on the same line showed significant differences $(\mathrm{P}<0.05)$. 
Bali cattle have a high body height in the mediumlands when compared to the lowlands and highlands. Meanwhile, the breast circumference of Limousine crossbreed cattle is higher in the highlands. The table demonstrates that the dimensions of the body height of cows reared in the moderate plains are statistically significant $(\mathrm{P}<0.05)$ compared to the Balinese cows raised in the lowlands and highlands. However, the dimensions of body length and chest circumference Bali cattle show no difference. The highest average length is obtained in the medium plains with an average value of 116.26, the highlands of 115.52 and the lowest in the lowlands with $113.10 \mathrm{~cm}$. Chest circumference obtained the highest value in the highlands which is $156.10,151.26$ for medium plains, and $146.89 \mathrm{~cm}$ for lowlands. Body length is closely related to bone growth which indicates that the performance data of Bali cattle production is more comfortable in medium and highlands compared to lowlands. The results were lower than those of [21] that obtained a chest circumference of 165.43, body length of $117.19 \mathrm{~cm}$ of Bali cows raised in Jembrana Regency in Bali. Factors that affect body size are age, breed, sex, feed, birth weight, environment and maintenance management.

The performance of the Limousine hybrid is shown in Table 3. The statistical analysis illustrates the size of the height and body length at the three maintenance locations show no significant difference. However, the size of the breast circumference of Limousine hybrid raised in the highlands has a significant effect $(\mathrm{P}<0.05)$ compared to the cows raised in the medium and lowlands. This difference is probably due to the low air temperature in the highlands which is $21.20^{\circ} \mathrm{C}$ compared to the medium and low plains (table 1). The results of [21], study found that the chest circumference value in the lowlands was 165.13 , the moderate plains were 160.00 and 162.14 for the highlands during the rainy season in Lampung.

Since the study revealed new output, a recommendation for the development of beef cattle in Sinjai regency are classified as follows; Bali cattle are seen from their production performance based on their height and body length which are suitable to be maintained at the height of the rearing site in the mediumlands above 100-400 masl, while the Limousine hybrid are more suitable to be maintained in the highlands which above 500 masl.

\section{Conclusions}

The altitude for keeping Bali cows and Limousine cows has an effect on the microclimate conditions; air temperature and humidity in the highlands. The height of the rearing site also affects the height of the Bali cattle, and the chest circumference of the Limousine hybrid. Respiratory and pulse rates are lower at high altitudes. The height of the breeding ground also affected the height of the Bali cattle, and the chest circumference of the Limousine hybrid.

\section{Acknowledgment}

The authors grant the gratitude to the Directorate of Research and Community Service, Ministry of Research and Technology of the Republic of Indonesia for providing research funding in order this research can be carried out. Besides, the authors thank the students of the Animal Science Study Program who had helped a lot in completing this research.

\section{References}

[1] D. J. Peternakan, Statistik Peternakan Dan Kesehatan Hewan 2018/ Livestock And Animal Health Statistics 2018. Direktorat Jenderal Peternakan Dan Kesehatan Hewan Kementerian Pertanian $\mathrm{Ri}, 2018$.

[2] F. E. P. Suhudiyah, E. Susanto, And Muridi Qomaruddin, "Pengaruh Penambahan Ampas Kecap Pda Jerami Fermentasi Terhadap Kualitas Fisik, Ph Dan Pertambahan Bobot Badan Sapi Brahman Cross (Bx)," J. Ternak, Vol. 59, No. 9-10, 2014.

[3] D. Suherman, S. Muryanto, And E. Sulistyowati, “Evaluasi Mikroklimat Dalam Kandang Menggunakan Tinggi Atap Kandang Berbeda Yang Berkaitan Dengan Respon Fisiologis Sapi Bali Dewasa Di Kecamatan Xiv Koto Kabupaten Mukomuko Microclimate," J. Sain Peternak. 
Indones., Vol. 12, No. 4, Pp. 397-410, 2017.

[4] E. L. Aditia, A. Yani, And A. F. Fatonah, "Respons Fisiologis Sapi Bali Pada Sistem Integrasi Kelapa Sawit Berdasarkan Kondisi Lingkungan Mikroklimat," Aditia Al. J. Ilmu Produksi Dan Teknol. Has. Peternak., Vol. 05, No. 1, Pp. 23-28, 2017.

[5] P. M. Serang, I. N. Suartha, And I. P. G. Y. Arjentinia, "Frekuensi Respirasi Sapi Bali Betina Dewasa Di Sentra Pembibitan Sapi," Bul. Vet. Udayana, Vol. 8, No. 1, Pp. 25-29, 2016.

[6] S. Kadarsih, "Performans Sapi Bali Berdasarkan Ketinggian Tempat Di Daerah Transmigrasi Bengkulu," J Ilmu-Ilmu Pertan. Indones., Vol. 6, No. 1, Pp. 50-56, 2004.

[7] D. V Armstrong And A. Sciences, "Heat Stress Interaction With Shade And Cooling," J Dairy Sci, Vol. 77, Pp. 2044-2050, 1994.

[8] U. Paputungan, L. Hakim, G. Ciptadi, And H. F. N. Lapian, "The Estimation Accuracy Of Live Weight From Metric Body Measurements In Ongole Grade Cows," J.Indonesian Trop.Anim.Agric., Vol. 38, No. 3, Pp. 149-155, 2013.

[9] A. . Ige, T. . Adedeji, L. . Ojedapo, S. . Obafemi, And O. . Ariyo, "Linear Body Measurement Relationship In White Fulani Cattle In Derived Savannah Zone Of Nigeria," J. Biol. Agricuture Healthc., Vol. 5, No. 15, Pp. 1-7, 2015.

[10] M. Kaps And W. Lamberson, Biostatistics For Animal Science. Usa: Cabi Publishing, 2004.

[11] I. M. Nuriyasa, G. A. M. K. Dewi, And N. L. G. Budiari, “Temperature Humidity Index And Physiological Responses Of Bali Cattle With Feedlot System Housed At Different Altitude," Maj. Ilm. Peternak., Vol. 18, No. 1, Pp. 5-10, 2015.

[12] V. Gantner, T. Bobic, R. Gantner, And M. Gregic, "Differences In Response To Heat Stress Due To Production Level And Breed Of Dairy Cows," J Biometeorol, 2017, Doi: 10.1007/S00484-017$1348-7$.

[13] T. L. Mader, M. S. Davis, And T. Brown-Brandl, "Environmental Factors Influencing Heat Stress In Feedlot Cattle," J. Anim. Sci, Vol. 84, Pp. 712-719, 2006, [Online]. Available: Http://Digitalcommons.Unl.Edu/Animalscifacpub Part Of The Animal Sciences Commons\%0amader,

[14] N. D. Suretno, B. P. Purwanto, R. Priyanto, And I. Supriyatna, “Evaluasi Kesesuaian Lingkungan Berdasarkan Penampilan Produksi Empat Bangsa Sapi Pada Ketinggian Berbeda Di Provinsi Lampung," J. Vet., Vol. 18, No. 3, P. 478, 2017, Doi: 10.19087/Jveteriner.2017.18.3.478.

[15] I. . Nuriyasa, E. Puspani, I. Sumatra, P. Wibawa, And I. Mudita, "Peningkatan Efisiensi Produksi Ayam Petelur Melalui Peningkatan Kenyamanan Kandang Di Desa Bolangan," Undayana Mengabdi, Vol. 9, No. 2, Pp. 55-58, 2010.

[16] Yaetmaneli, B. P. Purwanto, R. Priyanto, And W. Manalu, "Iklim Mikro Dan Respon Fisiologis Sapi Pesisir Di Dataran Rendah Dan Dataran Tinggi Sumatera Barat," J. Agripet, Vol. 20, No. 2, Pp. 126-135, 2020.

[17] Hermawansyah, Salundik, And Rudy Priyanto, "Physiological Response Of Reared Bali Cattle Based On Different Peat Land Characteristics," Chalaza J. Anim. Husb., Vol. 1.5, No. 1, Pp. 12 21, 2020, [Online]. Available: Url: Http://Usnsj.Com/Index.Php/Cjah.

[18] Dwatmadji, T. Suteky, E. Soetrisno, Bejo, And B. Manurung, "Kemampuan Kerja Sapi Bali 
Pada Sistem Integrasi Sapi-Kelapa Sawit Di Bengkulu," In Seminar Nasional Sistem Integarasi Tanaman-Ternak, 2000, Vol. 39, Pp. 491-495.

[19] R. Frandson, Anatomi Dan Fisiologi Ternak, 4th Ed. Yogyakarta: Universitas Gadjah Mada, 1992.

[20] P. J. Hansen, "Physiological And Cellular Adaptations Of Zebu Cattle To Thermal Stress," Anim. Reprod. Sci., Vol. 83, Pp. 349-360, 2004, Doi: 10.1016/J.Anireprosci.2004.04.011.

[21] N D. Suretno, Evaluasi Kesesuaian Lingkungan Empat Bangsa Sapi Berdasarkan Kondisi Fisiologis Dan Produktivitas Di Provinsi Lampung. Bogor, 2016. 